\title{
POLITICS AS RHETORIC: A DISCOURSE ANALYSIS OF SELECTED PAKISTANI POLITICIANS' PRESS STATEMENTS \\ Muhammad Ramzan $^{1}$, Abdul Waheed Qureshi ${ }^{2 *}$, Abdus Samad ${ }^{3}$, Neelam Sultan ${ }^{4}$
}

${ }^{1}$ MPhil English Linguistics, Lahore Leads University, Lahore, Pakistan; ${ }^{2 *}$ Assistant Professor, Department of English, Abdul Wali Khan University, Mardan, Pakistan; ${ }^{3}$ Assistant Professor/Chairman Department of English, Kohat University of Science and Technology, Kohat, Pakistan; ${ }^{4}$ Visiting Lecturer Department of English, Khushal Khan

Khattak University, Karak, Pakistan.

Email: *waheedqureshi@awkum.edu.pk

\section{Article History: Received on $14^{\text {th }}$ June 2021, Revised on $19^{\text {th }}$ June 2021, Published on $22^{\text {nd }}$ June 2021}

\section{Abstract}

Purpose of the Study: This paper aims at unveiling the linguistic repertoire through the analysis of the press statements of the leading figures of the then ruling party of Pakistan (Pakistan Muslim League (Nawaz Group) - PMLN and the opposition party there (Pakistan People's Party (Parliamentarians) - PPPP. The main focus of this research is to reveal the language game of key politicians who seem anxious to complete their tenure irrespective of the issues faced by the people and usurpation of their basic rights.

Methodology: For highlighting the hidden meanings in language usage, the researchers have deployed the approach of Gee's (2011) seven building tasks of language, for the accomplishment of the study objective.

Main Findings: The study findings indicate the manipulation and exploitation of the public by politicians through the game of words, shrouded in manifestos of prosperity/development, leading consequently to deterioration of the law-andorder situation, unemployment, nepotism, poverty, and black-marketing.

Applications of the Study: The Study can help those working in critical linguistics, discourse studies, hermeneutics, and textual studies.

Novelty/Originality of the Study: The study is significant and unique because it is the first of its kind that makes the discourse opposition party a holistic one by focusing on the perspectives of the key figures of the opposition in government. It is not a case study related to a single politician and their outlook(s).

\section{Keywords: Discourse Analysis, Government, Language, Opposition, Politicians.}

\section{INTRODUCTION}

Generally, in the world and particularly in Pakistan, political Discourse reflects various ideologies, power issues, ambiguities, and doubts. Language manipulation and discursive strategies are supposed to be important routes for political development everywhere. Likely, in Pakistan also, politicians always seem determined and motivated for the persuasion of their supporters and achieving their hidden motives concealed in manifestoes for 'prosperous' Pakistan, i.e., "it is strategic for politicians to use political rhetoric to persuade people to act in the way they (politicians) want" (Jalilifar \& Alvi, 2011). It is a known fact that media has been acknowledged as an extraordinary strength for the prosperity of democracy because it functions as a bridge between the rulers and the public, and its role and power in the development of democratic institutions can surely be overemphasized. Van Dijk (1989) focuses on how social power abuse is done and injustice created in politics through language. The research also aims to describe, understand and expose social and political injustice as the statements of the elected politicians in Pakistan reflect a few hidden agendas driven by political motives like manifestoes of development and the underhand and alleged deal between the then government and opposition for completing five years stint irrespective of their differences; the pacification of the public sentiments, at the same time, also went on parallel, as a result of which, unemployment, corruption, nepotism, and poverty increased alarmingly. Thus, it becomes visible that the government was propagating, and the opposition was mediating for their interests and benefits through the hollow slogans of prosperity and development.

\section{LITERATURE REVIEW}

According to Fasold (2017), any aspect of the language study is known as Discourse. Regarding this aspect, the social truths in the form of ideologies, theories, and perspectives are also the Discourse concern (Hansen, 2016). The various ideologies, theories, and perspectives become real when dealt with in Discourse, as though it is a discourse that gives them credibility. Therefore, according to Jørgensen and Phillips (2012) (Discourse), reality exists through this un-existing nature of language where meanings are catered metaphorically to mean differently, i.e., the deeper structure of the text. Discourse is also known as a segment of linguistic expressions or thoughts that is not limited to the sentence level. In other words, Discourse is a linguistic fragment or substance which helps transfer meanings towards others, more specifically, the implied meanings which work silently and purposefully (Rocci, 2009; Ullah, 2021). In the same way, in the opinion of Payne and Barbera (2010), the concept of Discourse is conversational as it often represents any conversation (written or oral) in which participants are active in their due roles to subdue one another by trying to achieve their hidden agendas. Fasold (2017) also says that the Study of any viewpoint in the use of language is known as Discourse. How the language works in various contexts and how it is used and unveiled in society is the aim of discourse 
analysis. Coulthard (2016) opines that the worth of discourse analysis is the construction of a message and its transmission to the listeners, the diction, movement, and plot. In the same way, discourse analysis is done to know the value of words that are socio-culturally significant for the listener to achieve the goal (of getting the hidden meanings) (Ramsay, 2018). So, Discourse Analysis is the Study of language in use. There are various approaches to discourse analysis. According to Gee (2011), some of them focus on the content of language, and the rest work on the structure (grammar) of language.

Van Dijk (1998) believes that the abuse of power is the main concern in (Critical) Discourse Analysis. It examines how power is abused in Discourse by exploiting people's faith. It is also seen how the thoughts and minds of less powerful strata in society are dominated through language ideology. He further says that social power is finally a way towards fame, knowledge, force, money, and status. The potential alliances always dominate, rule, and command the public's minds through manipulation and discursiveness in the practices of these powers. Relating discourse analysis to the same power dimension, Howarth (2017) asserts that it (discourse analysis) is the Study of any social system (politics in the present study) as a whole and its policies; that is to say, how that particular system came into being through its erected policies, how those policies were exercised and on whom. Fairclough and Wodak (1997) opine those social problems are addressed in (Critical) Discourse Analysis. According to them, (C)DA considers that power relations are discursive; society and culture are produced in Discourse, and ideology is reflected in the Discourse. Political Discourse is a secondary form of Discourse that can be stated in two ways, i.e., functional and thematic. Politics creates political speeches, and these speeches are determined historically and culturally. In politics, topics are always associated with political ideas, actions, and movements, making politics thematic (Fairclough, 1995). The speakers adopt many strategies and techniques in language to promote political campaigns, movements, and thoughts. For the exact knowledge of Discourse, these approaches are very necessary to understand. The experts in (C)DA contribute a plan to the abuse of power and recurrent social practice, which the cause of fluctuation in the society. In the same way, in the perspective of Harvey (2016), the basic aim of (C)DA is associated especially with the construction of a world in Discourse. This construction is done through the discursivity in language, perpetuated in the many different shapes and forms that language adapts.

Wodak and Meyer explain this discursivity "to survey opaque as well as transparent structural relationships of dominance, discrimination, power, and control manifested in the language" (Wodak and Meyer, 2018, p. 2). Furthermore, (Critical) Discourse Analysis contemplates social interaction and mostly broad illustrations partially embedded in the form of language. The critical theory is unique in two ways. It looks at the association between society and language simultaneously; it focuses on analyzed practice and interpretation (Fairclough \& Wodak, 1997). On the whole, discourse analysis aims to predict, run, and draw again from the notions of the people in society who participate in multiple settings and situations, i.e., discourses. Qureshi (2014) thinks that it is a language that shapes the different experiences of life in society and culture and moulds everything. Language/discourse thus shapes our thinking and ideology, and its analysis lets us understand the mechanisms behind its production and perpetuation. It does not study language superficially, but "rather it studies language how it should be or might be according to the participants' wishes. It is, in this way, that many other aspects above the pure structure of language do interfere and become the subject of Study for DA (discourse analysis) [parenthesis added]". Luu (2016) asserts the intriguing capacity of the language of the political speakers and says that often the masses are unaware of the intrigues of the political leaders. They believe in them blindly and whatever they are told without the least attention paid to the language of these speakers. It is this inattentiveness to the seemingly unimportant details which makes the common masses easily manipulated. According to Luu, "the more subtle the manipulation of language and the more unobtrusive the word-as-weapon becomes, the more insidious its effect on an unsuspecting public" (Luu, 2016).

\section{The rationale of the Study}

Many developments in discourse analysis have been made during the past few years, but challenges still exist. Keeping in view PML (N) Government (2013-2018) propaganda and its collaboration with the opposition to perpetuate their political motif, this research is aimed to highlight linguistic agenda and political motives in Pakistani politicians' Press Statements. This research will enhance the political parameters of Discourse by the analysis of the selected press statements within the socio-cultural make-up of Pakistani society. As the limited understanding of language manipulation creates many problems like difficulty in understanding the customs and habits of various societies, handling and managing social and public affairs leading to the attainment of professional goals and meeting the assigned destination in time, the researchers felt an urgent need to take steps to evolve a holistic study to resolve many of the national issues by diverting public attention to the rhetorical techniques of the politicians. This research will fill the gap between the Pakistani public and the Pakistani politicians by understanding the linguistic strategies used by these politicians for the manipulation/exploitation of the common masses.

\section{Research Objective}

The current research aims to build a capacity to understand language manipulation by politicians at the national level in Pakistan. 


\section{Research Question}

How do politicians in Pakistan use language to serve their own needs?

\section{Data Sampling}

The textual data in the form of press statements were sampled under the purposive sampling technique. This sampling technique enabled the researchers to collect data easily and with a particular focus using rhetoric for public convincing. However, as this depends upon the researcher(s) to include those participants/cases who can best represent the theme (Etikan et al., 2016), these researchers decided to include only the mentioned politicians' press statements for analysis.

\section{METHOD AND MODEL OF ANALYSIS}

The method used for the analysis of data was discourse analysis by Gee (2011). His model has 'seven building tasks of the language' which are:

\section{Significance}

Each and everything in the universe have a certain significance. However, in society, somewhere, the members ascertain this significance using exaggeration and elsewhere, they try to minimize this significance by using their rhetoric to let others know how they (members) view this significance.

\section{Practices}

Practices are the social or organizational commissions that usually entail performing certain tasks in peculiar ways. As language is at the base of recognizing every action (task), which makes it a specific discourse, the 'action form' becomes an activity. Both of them, i.e., language and the activity that it produces, are in a mutual relationship as existence is impossible without the existence of the other. If we think it right, what then is the position of new practices? The answer is that new practices arise out of the older practices with transformation and amalgamation. Practices see as what kind of activities are enacted in the statements to make others reconcile with what is going on, is supposedly true.

\section{Identities}

Identity is a way of representing oneself. Identity making/getting works in a reciprocal relationship with some other identity that is to say that getting an identity for ourselves, we first give identity to others. People express identities in their statements by hiding their real intentions and attribute positive roles to themselves by making others manipulate through rendering them the identity of fools.

\section{Relationships}

Language is used for the determination of relationships with the readers/audience/hearers. Different techniques are used to discuss these relationships through levels of formality and informality, political rhetoric, direct assertions, etc.

\section{Politics}

Politics is the technique with which public good is conveyed to the masses in different and tricky ways - sometimes positively and other times showing their negative effects, though concealing this negativity. So it is observed the demagogues' highlighting their so-called social good by concealing its ill-effects in their language and the kind of benefits being achieved by them.

\section{Connections}

Connections or breaks are created in language. However, things are not always inherently connected, and language plays a role to connect them in different subtle ways. In the same way, the already established connections are also lost with the discreet use of language.

\section{Sign Systems and Knowledge}

It means using different varieties of the same language, jargon, register, code-switching, numbers, numeric, images, gestures, mocking, parody, etc., in speech or writing to create a particular effect. For example, the user may be to get attention or give credibility to one's assertions. It may also be used for emphasis and comparing the present discussion with the past discourses, for example, giving a percentage of the ratio of the current development, compared to the previous governments. In any case, the purpose is self-idealization and self-actualization.

The present research has tried to unravel the building mentioned above language tasks by analyzing and interpreting the selected statements (press releases) of Pakistani politicians.

\section{DATA PRESENTATION AND ANALYSIS}

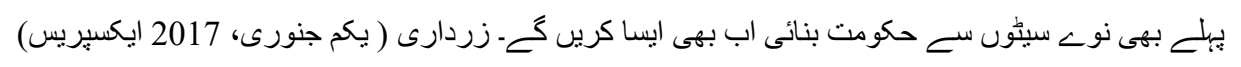

Roman Transliteration: Pehlay bhi nawway seaton say hukumat banai ab bhi aisa karen gay. Zardari (yakam January, 2017 Express) 
English Translation: Previously also, we made the government with ninety seats, now too will do the same (Zardari, $\underline{2017)}$

\section{Analysis and Interpretation}

According to Gee (2011), in Discourse, we need to know the context, make assumptions, draw inferences and think about information to make out the real sense of speech based on what was said by the speaker. In the above press statement, the context is that the political party of Mr. Zardari (Pakistan Peoples Party Parliamentarians) has passed almost four years in sitting at the opposition bench in the federal cabinet, and he is addressing his voters as a cochairman of PPPP. In the given statement, he highlights the significance of the public with the available evidence of individual power and expectations. He is proclaiming to his voters that the turn of the PPPP government will come very soon by asserting the previous fact where they made the government with (Transliteration: nawway Seaton), i.e. (Translation: ninety seats). Moreover, Zardari identifies himself as enjoying the unique social status and distinguished, powerful personality by giving his statement credibility through (Transliteration: ab Bhi Aisa Karen gay), i.e. (Trans: now too will do the same). His statement shows that the connections between Zardari and his voters are irrevocable. He is trying to promote his connection with voters and party workers using the modal verb (Transliteration: gay), i.e. (Translation: will). He is thinking about the next coming election, and in his statement, he reassures his party voters that PPPP will emerge as the next governing party. The modal verbs are used to indicate moods, which perform the role of renowned persuasive strategies. The modal verbs (modal auxiliaries) describe obligation, possibility, permission, ability, uncertainty, and necessity. Cameron (2017) says that it (modal verb) allows people to formulate different kinds of claims, e.g., assertions, opinions, hypotheses, speculations, and indicate how committed they are to those claims.

Similarly, Zardari looks highly optimistic in the given statement, as well as determined in achieving government authority after the coming elections for five years. The use of modality reflects his trust in his party's workers, which develops enthusiasm in his voters about political strategies in the future and completion of the promises. Zardari promotes his significance by using the phrase (Transliteration: ab Bhi Aisa Karen gay), i.e. (Trans: now too will do the same). It indicates that Zardari is fully confident that PPPP will make government at all costs in the next elections. (Transliteration: gay) alludes to Zardari's perspective of communal strife, i.e. (Translation: we) in the form of the plural pronoun. Alvi and Baseer (2016) say that responsibilities are distributed by using the plural pronoun. In an unfavourable situation, the responsibilities are put on the audience's shoulders by using the plural pronoun. It also reduces the gap between hearer and speaker. Zardari is addressing not only PPPP workers but also the allied parties. He is again inviting all those parties that were part of his previous government alliance to participate again to make government after the next elections.

Furthermore, the use of modality helps to conceal his commitment and promise. Similarly, in the given statement, he has used the commissive speech act, which propagates that the speaker (Zardari) describes the obligations and has some intentions to do in the future. In other words, it can be said that Mr. Zardari is using pragmatic strategies and is alluring the public with linguistic fascination.

$$
\text { بار رثى منشو ر ميس صنعت و ز را عت كو نر جيح ديس گَحــ بلا ول (22 جنو رى،2017 ايكسبريس) }
$$

Roman Transliteration: Party Mansoor may Sanat was zarat ko tarjeeh den gay (Bilawal, 2017) (January 22, 2017 Express).

English Translation: In the party manifesto, we will give priority to industry and agriculture (Bilawal, 2017).

\section{Analysis and Interpretation}

The Discourse digests all created and constructed ideologies. Furthermore, political Discourse is associated with the production and maintenance of political ideologies and is resisted in it (Van Dijk, 2014). Similarly, the relationship between power and language also exists and is developed and maintained in Discourse (Fairclough, 2000). So, Bilawal, in the above statement, is trying to create a new ideological stance by using two main resources of the country (Transliteration: Sanat wa zarat), i.e. (Translation: industry and agriculture). This assertion works as a presupposition that priority is not given to these resources by the present government PML-N in its tenure. He is the Chairman of PPPP, and he uses the power of industry and agriculture in his language for onward manipulation to promote his party ideology regarding the upcoming elections of 2018 while simultaneously making the public mediate by not directly addressing and blaming the previous government for the backwardness of industry and agriculture. He is given promoting his significance by giving the plan of his future strategies. He produces his unique identity in the given statements and does not condemn the present government's policies directly, like a motorway, metro bus, and orange line train.

In the statement, commitment and responsibility are also visible. Bilawal presents himself as a representative of the community and shows his willingness of serving them. He implicitly assures his voters and party workers that he will never disappoint them and work for their prosperity and promotion. The statement reveals that his attitude towards the audience is very frank and friendly. He is trying to bridge the gap between him and his voters with the help of such rhetoric. The word (Transliteration: gay), i.e. (Translation: will) is employed as a modal verb which he uses to reveal the sense of collective responsibility between his audience and him as the co-chairman of PPPP, and it indicates that both the speaker (Bilawal) and the audience are focused on going towards the same destination. In the above statement given 
by the PPPP Chairman, we come to know that his main concern is linked with the need to meet his end with the persuasion of the Pakistani public, and he is fully aware of the issues like agriculture and industry. Similarly, in the given statement, Bilawal is also using the commissive speech act and is trying to allure the public again for his hidden agenda with the help of practical techniques because it is a known fact that speaker/address or always describes the obligations in commissive speech acts. Bilawal is trying to promote the public seductiveness for personal interest in public with the help of language.

$$
\text { وزير آ عظم كو مو ثر و ـ بننه ميس اموات, بها رى ثول ثيكس سـ آ كاه كر ديا- وزير ا على سنده (5 فر ورى، } 2017 \text { ايكسبريس) }
$$

Roman Transliteration: Wazir Azam ko motorway ban'nay may amwat, bhari toll tax say aaagh kar dia.

English Translation: (We) informed the Prime Minister about deaths, heavy toll during motorway construction (Chief Minister Sindh, 2017).

\section{Analysis and Interpretation}

In the above-given statement, Chief Minister Sindh, Syed Murad Ali Shah, says that he has informed Prime Minister Mian Muhammad Nawaz Sharif about the expected deaths and heavy toll taxes which will have to be paid to the provinces during and after the construction of the motorway. In the statement, the speaker attacks his opponent PML (N) in a very subtle manner and indirectly condemns the federal government policies regarding making the motorway from Multan to Karachi. Chief Minister Sindh wants to glorify himself and his party by paying sympathies towards the national taxpayers because it looks very strange and ironical on the part of the Chief Minister to favour the public in (not) paying heavy taxes. There is also an exaggeration in the statement. He projects a positive image of speakers and his party members and a negative image of the federal government with death, toll, and heavy taxes. In the given text, the Chief Minister endeavours to deface the image of PPPP opponents. It is an implicit way to maintain power and impose specific ideologies on the public. There is a negative connotation in the speaker's statement, which indicates the ideological bias and differences of speakers and his party with the federal government. By conveying this statement from the PPPP leader implicitly, it is being tried to restore the confidence of the masses in Sind province and other parts of the country. Moreover, the Chief Minister is trying indirectly to convince the community to collect vote for PPPP in the future and reject the ruling party, i.e., PML (N).

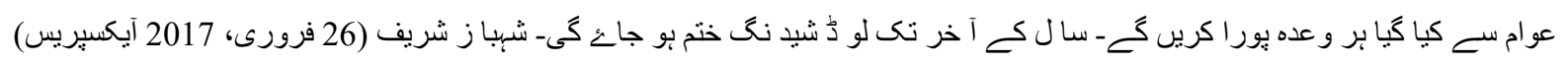

Roman Transliteration: Awam say kia gaya har wada poora karen gay. Saal kay akhir tak load shedding khatam ho jaye gi. Shehbaz Sharif.

English Translation: (We) will keep every promise made to the people. Load shedding will finish by the end of the year (Sharif, 2017).

\section{Analysis and Interpretation}

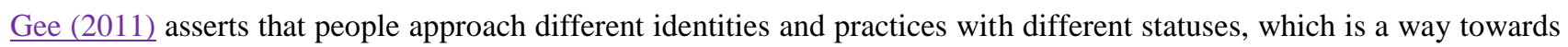
social discrimination. Different activities and identities are produced in language, which is directly associated with equity and justice. Similarly, PML (N) used 'electricity and load shedding as a basic plan towards achieving social goods in the previous success in 2013 elections. It was the basic slogan of PML (N) during the election campaign in 2013 and is still being used to complete their political goals. In the opposite sense, according to the above statement, Chief Minister Punjab (Mian Muhammad Shehbaz Sharif) is fully aware of the community's social needs and believes that electricity is the backbone of all industries and economic outcomes. Therefore, he uses the electricity problem as a social goods tool. He identifies himself as a responsible doer and tries to prove himself as a well-wisher of the community. In the given statement, he creates four types of identities, i.e., professional, social, institutional, and personal. In all sorts of identities, he is trying to promote the significance of his party and personality to develop connections between the public and himself. In the given statement, the modal verb is used twice. He uses the modalities for the sake of community manipulation. Cameron (2017) says that the modalities are used in language to produce various types of professed claims, and model auxiliaries describe abilities and obligations. Manipulation either requires power or demands the power abuse that is known as dominance. More significantly, manipulation suggests using illegal power in the Discourse. Manipulators promote the beliefs of other people and invite them for their interests. Similarly, Chief Minister Punjab also manipulates the Pakistani public because PML(N) has passed almost five years of its tenure as a dominating and governing political party. However, electricity issues and load shedding are still existing, whereas it was promised by PML(N) to finish these problems in the first year of its government.

$$
\text { دبشتكردونكه خلاف تيز ترين علالتى نظام لا ربـ بيس- جوبدرى نثار (15جنورى،2017 ا يكسيريس) }
$$

Roman Transliteration: Dehshat gardon kay khilaf tez tareen adalti nizam la rahay hain (Nisar, 2017).

English Translation: (We) are bringing the fastest judicial system against the terrorists (Nisar, 2017).

\section{Analysis and Interpretation}

Speakers leave things out always (leave things unsaid and assume they will be understood based on listeners' knowledge 
of the context in which communication occurs (Gee, 2010). Similarly, Interior Minister Chaudhry Nisar thinks that all the readers are aware that Pakistan is facing extreme terrorism and extremism, and terrorists are destroying the peace and prosperity in Pakistan. The physical settings that associate the communication, e.g., the gathering public/audience in the present statement and the shared cultural knowledge, are known as context. It can be inferred from the Interior Minister's speech that although Pakistan judicial system is active against arrested terrorists, yet Chaudhry Nisar looks more active and more determined to bring the fastest judicial system for them. He identifies himself as a responsible action taker in the capacity of Interior Minister and performing his utmost duties for enforcing the law and order situation against terrorists. He also terrifies the terrorists to give up terrorist activities by giving above mentioned statements. Gee (2011) says that subject is always an entity that is the centre of interest and attention in the utterances. It is also known as the theme of the statement, and the theme or topic of the utterance is called the central figure there. In other words, the whole utterance, actions, identities, and activities revolve around it. So, all these things are revolving around terrorists and terrorism. Although it is the responsibility and obligation of every Interior Minister to ensure a law and order situation in their country, Chaudhry Nisar, on the contrary, makes it political by proving himself as the nation's benefactor introducing the fastest judiciary system for the terrorists. So, it looks very ironic from his statement to bring the fastest judicial system.

\section{FINDINGS}

The paper aimed to investigate the politicians' language game in the statements of the newspapers as the main agenda. The researchers intended to derive certain techniques and strategies governing the text for abuse of power and implementation of a hidden agenda. Two types of politicians' language game, e.g., government and oppositions, are analyzed by applying the discourse analysis as a tool for data analysis, and results showed the following:

Table 1: The process and strategies used by the government and opposition in the language game

\begin{tabular}{llll}
\hline S. No. & Strategies/Process & Government Politicians & Opposition Politicians \\
\hline 1 & Proposition & + & - \\
\hline 2 & Mediation & - & + \\
\hline 3 & Persuasion & + & + \\
\hline 4 & Manipulation & + & + \\
\hline 5 & Pacification & + & + \\
\hline 6 & Stereotyped Constructions & + & + \\
\hline 7 & Fake Ideologies & + & + \\
\hline
\end{tabular}

Source: Collected Data Output

In all the selected statements, pacifying strategy from both government and opposition sides is achieved to neutralize the aggression and emotions of the nation to minimize the chance for revolutions. The positive proposition from the government side and mediation from the opposition' indicate that there might be an implicit deal between them. Politicians use manipulation, persuasion, and fake ideologies as a source for power abuse to attain their hidden goals. The government performs a propositional role, and the opposition mediates to befool the whole nation.

\section{CONCLUSION}

The findings of this research explicitly indicate the maltreatment of the public by politicians through the game of words, shrouded in manifestos of prosperity/development and, consequently, which cause of deterioration of law and order situation, unemployment, nepotism, poverty, and black-marketing which indirectly and in numerous subtle ways blame and support terrorism and extremism in Pakistan. Finally, the analysis also gives glimpses of dissatisfaction over the governments and the opposition's role in Pakistan.

\section{LIMITATION AND STUDY FORWARD}

The data for this study comprises of the selected press statements of the President Opposition Party (PPPP)-Pakistan, Asif Ali Zardari; Chairman Opposition Party (PPP)-Pakistan, Bilawal Bhutto Zardari; Chief Minister Sindh, Syed Murad Ali Shah; Chief Minister Punjab, Mian Muhammad Shehbaz Sharif; and Interior Minister of Pakistan, Chaudhari Nisar Ali Khan. The current research is based upon the selected politicians' selected press statements only during the era 20132018, and the results cannot be generalized inclusively to all other politicians at other times or the same politicians at other times. The present study navigates the future studies in the same line in the context of other Asian countries. Furthermore, the present study can be expanded by comparing two or more nations as well as comparing Asian countries with European economies.

\section{ACKNOWLEDGEMENT}

The researchers acknowledge their fruitful discussion among themselves first and other colleagues at their respective departments. The principal author is especially thankful to the public library of Nowshera, Khyber Pakhtunkhwa Pakistan, to render him the newspapers from its archives. 


\section{AUTHORS CONTRIBUTION}

Muhammad Ramzan contributed to data collection and 'Introduction' writing and provided the title for the article. Abdul Waheed Qureshi contributed to writing' Literature Review' and 'Rationale of the Study', correspondence with the journal, and reviewed after completing the article. Abdus Samad contributed to writing' Analysis and Interpretation', and 'Methodology'. Neelam Sultan contributed to writing' Objective', 'Research Question', 'Conclusion, and 'References'.

\section{REFERENCES}

1. Alvi, S. D., Baseer, A. (2016). An investigation of the political discourse of the Obama's selected speeches: a hallidian perspective. International Journal of Humanities and Social Science, 1(16), 57-63.

2. Bilawal (2017). In the party manifesto, priority will be given to industry and agriculture. بار رنى منشو ر مين صنعت [Press statement in the Daily Express]

3. Cameron, D. (2017). The teacher's guide to grammar. Oxford: Oxford University Press.

4. Chief Minister Sindh. (2017). Informed the Prime Minister about deaths, heavy toll during motorway

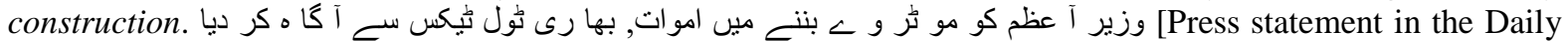
Express]

5. Coulthard, M. (2016). An introduction to discourse analysis. Applied Linguistics and Language Study. Harlow, UK: Longman, ( $2^{\text {nd }} e d$.).

6. Etikan, I., Musa, S. A., \& Alkassim, R. S. (2016). Comparison of convenience sampling and Purposive sampling. American Journal of Theoretical and Applied Statistics, 5(1), 1-4. https://doi.org/10.11648/j. ajtas.20160501.11

7. Fairclough, N. (1995). Critical discourse analysis. London: Longman.

8. Fairclough, N., \& Wodak, R. (1997) Critical discourse analysis. In van Dijk, T. (ed.). Discourse as social interaction, 2(3), 258-284.

9. Fairclough, N. (2000). Discourse, social theory and social research: the case of welfare reform. Journal of Sociolinguistics, 4(1), 163-95. https://doi.org/10.1111/1467-9481.00110

10. Fasold, R. (2017). Sociolinguistics of language. Oxford: Blackwell.

11. Gee, J. P. (2010). How to do discourse analysis: A toolkit. Tylor and Francis: New York, (1 ${ }^{\text {st }}$ ed.). https://doi.org/10.4324/9780203850992

12. Gee, J. P. (2011). An introduction to discourse analysis: Theory and method. Routledge: New York, ( $3^{\text {rd }}$ ed.).

13. Hansen, L. (2016). Security as practice: Discourse analysis and the Bosnian war. The New International Relations, 12(2), 451-462.

14. Harvey, D. (2016). Justice, nature and the geography of difference. Oxford: Blackwell.

15. Howarth, D. (2017). 'Discourse'. Concepts in the Social Sciences. Buckingham: Open University Press.

16. Jalilifar, A. R., \& Alavi, M. (2017). Power and politics of language use: A survey of hedging devices in political interviews. The Journal of Teaching Language Skills, 7(4), 342-361.

17. Jørgensen, M., \& Phillips, L. (2012). Discourse analysis: As theory and method. London: Sage.

18. Luu, C. (2016). The linguistics of mass persuasion: How politicians make "fetch." happen (part 1). Retrieved on April 29, 2021, from https://daily.jstor.org/the-linguistics-of-mass-persuasion-how-politicians-make-fetchhappen/

19. Mills, S. (1997). 'Discourse'. The New Critical Idiom. London: Routledge.

20. Nisar, C. (2017). Bringing the sharp judicial system against the terrorists. دبشتكردونكح خلاف تيز ترين علالتى نظام لا ديـ [Press statement in the Daily Express]

21. Payne, M., \& Barbera, R. J. (2010). A dictionary of cultural and critical theory. West Sussex: WileyBlackwell. https://doi.org/10.1002/9781444323450

22. Qureshi, W. A. (2014). Oppression of women in patriarchal societies: An analytical study of Anita Shreve's novels (Unpublished doctoral dissertation). National University of Modern Languages, Islamabad, Pakistan.

23. 23. Ramsay, G. (2018). Shaping minds: A discourse analysis of Chinese language Community mental health literature. Discourse Approaches to Politics, Society and Culture, 32. Amsterdam: John Benjamins Publishing Company.

24. Rocci, A. (2009). Doing discourse analysis with possible worlds. In Renkema, J. (Ed.), Discourse, of course: An overview of research in discourse studies, 3(5), 15-35. https://doi.org/10.1075/z.148.03roc

25. Sharif, S. (2017). Every promise made to the people. Load shedding will finish by the end of the year.

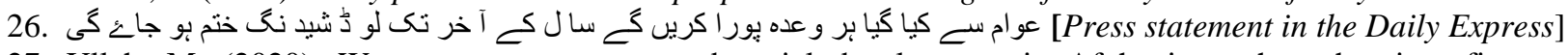

27. Ullah, M. (2020). Women empowerment and social development in Afghanistan through micro finance. International Journal of Academic Research in business and Social Sciences, 10(12), 377-389

28. Van Dijk, T. A. (1989). Structures of discourse and structures of power. In J. A. Anderson (ed.), Communication Yearbook, 12, 18-59. https://doi.org/10.1080/23808985.1989.11678711

29. Van Dijk, T. A. (2015). Text and context of parliamentary debates. In P. Bayley (ed.). Cross-Cultural Perspective on Parliamentary Discourse, 339-372. Amsterdam: Benjamins. https://doi.org/10.1075/dap sac.10.10dij

30. Wodak, R., \& Meyer, M. (2018). Methods of critical discourse analysis. London: Sage. 
31. Zardari, (2017). Previously also, we made the government with ninety seats, now too will do the same.

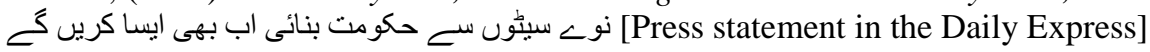

